\title{
Evolutionary and Pronostic Aspects of Cirrhosis at the University Hospital of Brazzaville (Congo)
}

\author{
Jile Florient Mimiesse ${ }^{1,2}$ (D), Ngalessami Mouakosso Marlyse ${ }^{2}$, Ahoui Apendi Clausina ${ }^{1,2}$, \\ Mongo Onkouo Arnaud1,2, Atipo-Ibara Ollandzobo Lucie', Firmin Bossali1, \\ Akoa Ngala Itoua-Ngaporo ${ }^{1,2}$, Rody Stéphane Ngami1,2, Mahoungou Gael Honal1, \\ Deby Gassaye ${ }^{1,2}$, Atipo Ibara Blaise Irénée ${ }^{1,2}$, Ibara Jean-Rosaire1,2
}

${ }^{1}$ Faculty of Health Sciences, Marien Ngouabi University, Brazzaville, Congo

${ }^{2}$ Gastroenterology Service, University Hospital of Brazzaville, Brazzaville, Congo

Email: jilemimiesse@yahoo.fr

How to cite this paper: Mimiesse, J.F., Marlyse, N.M., Clausina, A.A., Arnaud, M.O., Lucie, A.-I.O., Bossali, F., Itoua-Ngaporo, A.N., Ngami, R.S., Honal, M.G., Gassaye, D., Irénée, A.I.B. and Jean-Rosaire, I. (2020) Evolutionary and Pronostic Aspects of Cirrhosis at the University Hospital of Brazzaville (Congo). Open Journal of Gastroenterology, 10, 23-29.

https://doi.org/10.4236/ojgas.2020.101003

Received: August 26, 2019

Accepted: January 5, 2020

Published: January 8, 2020

Copyright () 2020 by author(s) and Scientific Research Publishing Inc. This work is licensed under the Creative Commons Attribution International License (CC BY 4.0).

http://creativecommons.org/licenses/by/4.0/

\begin{abstract}
Introduction: cirrhosis is a serious pathology that leads to complications whose management remains difficult in our country. This study aimed to evaluate the evolutionary aspects of cirrhosis at the Brazzaville University Hospital. Patients and methods: this was a retrospective study over a period of 18 months (from January 2015 to July 2016), performed in the Gastroenterology Department of the Brazzaville University Hospital. All patients regularly followed for decompensated cirrhosis were included. The studied variables were the epidemiological, clinical and paraclinical characteristics, the occurrence of complications, the survival, and the causes of death. Univariate analysis was used to determine prognostic factors based on the Child Pugh score. Results: There were 43 patients, including 32 men and 11 women, with a mean age of $52 \pm 9.5$ years. Viral hepatitis B was the most common etiology (39.5\%). Child Pugh stage $\mathrm{C}$ was found in $60.5 \%$. Oesophageal varices were present in $93 \%$ of cases. Survival at 18 months was $72 \%$. In univariate analysis, two variables were significantly associated with decreased survival, including Child Pugh stage $\mathrm{C}$ and esophageal varices (grade II and III). Conclusion: cirrhosis remains a worrying pathology because the diagnosis is often made at the stage of often serious complications putting at risk of vital prognosis.
\end{abstract}

\section{Keywords}

Cirrhosis, Evolution, Brazzaville 


\section{Introduction}

Cirrhosis is the ultimate stage of evolution of chronic liver disease. It is a serious pathology whose evolution is peppered with complications that evolve towards death [1]. Early diagnosis involves the means of investigation, the most recent of which are the non-invasive tests for fibrosis [2]. The lifespan of patients with cirrhosis is influenced by etiological, sociodemographic factors, the stage of development at the time of diagnosis and the level of the technical plateau [3] [4] [5].

The management of cirrhosis and its complications is difficult in Congo, where the means of early diagnosis and specific therapeutic means are not available [4] [5].

In order to improve the management of cirrhosis and its complications, we conducted this study whose main objective was to evaluate the evolutionary aspects of cirrhosis.

\section{Patients and Methods}

This was a retrospective study from January 2015 to July 2016, for a period of 18 months. The study took place in the Department of Gastroenterology and Internal Medicine (GEMI) of the Brazzaville University and Hospital Center. We included patients whose discharge diagnosis was decompensated cirrhosis and who received regular follow-up after discharge. The diagnosis was made in the presence of signs of hepatocellular insufficiency, signs of portal hypertension and liver characteristics. Hepatic biopsy (PBH) was not performed due to lack of material for transjugular PBH and all patients were seen at the decompensation stage preventing transparietal PBH. Patients who died during hospitalization, who were released against medical advice or were lost to follow-up, were not included in the study. After discharge, all patients were reviewed one week later, then every two weeks, and once a month, depending on the outcome. The study variables were: socio-demographic (age, sex, occupation), reason for hospitalization, etiology of cirrhosis, Child Pugh stage, complications during follow-up, patient outcome, circumstances death, survival time and correlations between death and the variables studied. The size of our sample was evaluated by the Shwartz formula.

All data were collected on a survey sheet and analyzed on epi-info version 6.0). The Chi-square test was used to compare our results that were significant for a probability $\mathrm{p}<0.05$. The survival curve was made according to the Kaplan Meier Method.

\section{Results}

During the study period, 2312 patients were hospitalized in the GEMI department of the University Hospital of Brazzaville, including 203 cases (8.7\%) of cirrhosis. Forty-three cases meeting our inclusion criteria were selected.

Men accounted for $74.4 \%$ of cases $(n=32)$ and women for $25.6 \%$ of cases $(n=$ 
11). The sex ratio of 2.9. The average age was $52 \pm 9.5$ years with extremes ranging from 21 to 79 years. The most represented age group was 40 to 59 years old.

The average consultation time was 4 weeks with extremes ranging from less than a week to three months.

The most common clinical signs were ascitic and edema of the lower limbs (see Table 1).

In our study $60.5 \%$ of patients were classified as Child Pugh C, $30.9 \%$ were Child Pugh B and 9.2 were Child Pugh A.

Oesophageal varices were found in $93 \%$ of patients $(n=40)$ and HTP gastropathy in $25.6 \%$ of patients $(\mathrm{n}=11)$.

In $65 \%$ of the cases $(n=37)$ cirrhosis was viral in origin, related to $B$ virus in $39.5 \%$ of cases. The concept of oenolism was found in $20.9 \%$ of patients, $9.3 \%$ of whom were associated with the hepatitis B virus.

Regarding evolutionary data, the overall duration of follow-up was 18 months with extremes ranging from 6 to 18 months. The main complication during follow-up was refractory ascites (see Table 2).

In our study, overall survival was $72 \%$ according to the Kaplan Meier method (see Figure 1).

The main causes of death were hepatic encephalopathy in $36.4 \%$ of cases ( $\mathrm{n}=$ 4 ), gastrointestinal bleeding in $27.3 \%$ of cases $(n=3)$, hepatorenal syndrome in $18.1 \%$ of cases $(n=2)$, ascites fluid infection and hepatocellular carcinoma in $9.1 \%(\mathrm{n}=1)$ respectively.

In univariate analysis mortality was significantly related to the Child Pugh stage $(\mathrm{p}=0.0088)$ and to the presence of large oesophageal varices $(\mathrm{p}=0.01)$ (see Table 3).

Table 1. Distribution of patients by clinical signs.

\begin{tabular}{ccc}
\hline Clinical signs & Effective & $\%$ \\
\hline Ascites & 36 & 83.7 \\
Edema of the lower limbs & 31 & 72.1 \\
Hepatomegaly & 14 & 32.6 \\
Splenomegaly & 12 & 27.9 \\
Icterus & 11 & 25.6 \\
Circulation veineuse collatérale & 8 & 18.6 \\
Digital Hippocratism & 8 & 18.6 \\
Hepatic encephalopathy & 7 & 16.3 \\
Pleurisy & 6 & 14 \\
Melena & 3 & 7 \\
Signs of alcoholism & 2 & 4.7 \\
Hematemesis & 2 & 4.7 \\
Gynecomastia & 1 & 2.3 \\
Fetor hepatis & 1 & 2.3 \\
\hline
\end{tabular}




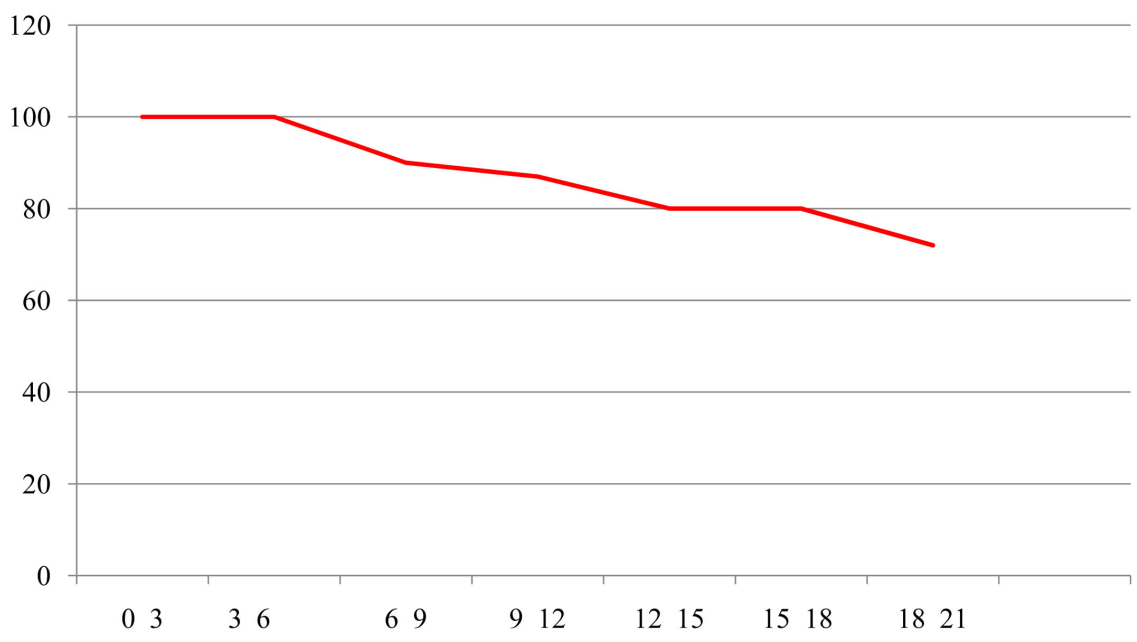

Figure 1. Kaplan meier survival curve.

Table 2. Distribution of patients by complications during follow-up.

\begin{tabular}{cccc}
\hline & $\begin{array}{c}6 \text { months } \\
\mathrm{n}=43\end{array}$ & $\begin{array}{c}12 \text { months } \\
\mathrm{n}=43\end{array}$ & $\begin{array}{c}18 \text { months } \\
\mathrm{n}=43\end{array}$ \\
\hline Ascites fluid infection & $6(13.9 \%)$ & $4(9.3 \%)$ & $3(7 \%)$ \\
Gastrointestinal bleeding & $6(13.9 \%)$ & $5(11.6 \%)$ & $4(9.3 \%)$ \\
Hepatic encephalopathy & $5(11.6 \%)$ & $6(13.9 \%)$ & $8(18.6 \%)$ \\
Hepatocellular carcinoma & $1(2.3 \%)$ & $2(4.6 \%)$ & $3(7 \%)$ \\
Hepatorenal syndrome & $1(2.3 \%)$ & $3(7 \%)$ & $3(7 \%)$ \\
Ascites or his aggravation & $22(51.1 \%)$ & $18(41.9 \%)$ & $27(62.8 \%)$
\end{tabular}

Table 3. Univariate analysis of death-related factors.

\begin{tabular}{cccc}
\hline & Living & deceased & Total \\
\hline Child Pugh Score & & & \\
A & $4(100 \%)$ & 0 & 4 \\
B & $13(100 \%)$ & $0(0 \%)$ & 13 \\
C & $15(57.7 \%)$ & $11(42.3 \%)$ & 26 \\
& $\mathbf{p}=\mathbf{0 . 0 0 8}$ & & \\
Gradeoesophageal varices & & $0(0 \%)$ & $3(100 \%)$ \\
Oesophageal varices I & $3(100 \%)$ & $1(5.9 \%)$ & $17(100)$ \\
Oesophageal varices II & $16(94.1 \%)$ & $9(45 \%)$ & $20(100 \%)$ \\
Oesophageal varices III & $11(55 \%)$ & & \\
& $\mathrm{p}=\mathbf{0 . 0 1}$ & & \\
& &
\end{tabular}

\section{Discussion}

Our study is limited by the mono-centric character and the small size of the sample limits us in the extrapolation of our results. 
In the Congo, cirrhosis is most often diagnosed in relatively young male subjects. These results are consistent with data published by several African authors [6] [7] [8] [9], because of the young age of the general population, but also because of the high prevalence of chronic carriage of hepatitis virus B.

The oedemato-ascitic syndrome was one of the main reasons for hospitalization in our study. This finding is similar to that reported by Yao Bataix and Diarra [7] [10]. The oedematous-ascitic syndrome has been described by Pariente [11] as a frequently revealing complication of the disease.

The delay in consultation found in almost $50 \%$ of cases is probably related to our cultural context where patients first resort to churches and traditional healers in case of illness, before going to the hospital in the absence of improvement.

The delay in the consultation probably explains in part the advanced stage of the Child-Pugh stage $\mathrm{C}$ in more than half of the patients. This is close to the results of Bossali in Pointe-Noire in Congo [5]. However, in the studies of Yao Bataix and Karoui [7] [12], the stage at diagnosis is relatively less advanced, mainly stage B of Child Pugh.

Oesophageal varices are the most frequently found endoscopic signs, but the endoscopic stage is variously appreciated by the authors. In our work there is a high frequency of esophageal varices stage III, which corroborates the work of Diarra in Mali [10] and Moulion Tapouh in Cameroon [13] with respective frequencies of $67.23 \%$ and $82.4 \%$ of cases. On the other hand Yao Bathaix et al. [7] found a predominance for oesophageal varices stage II (51.32\%). All of these studies confirm the advanced stage of diagnosis in African countries. In Caucasian series, however, the frequency of stage 3 varices is generally less than $30 \%$ [3].

Viral hepatitis is the most common cause of cirrhosis in our study with a predominance of hepatitis B. These results are similar to those of Sehonou in Benin [14] and Yao Bathaix in Côte d'Ivoire [7] who recovered hepatitis B respectively in $30.8 \%$ and $76.04 \%$ of cases.

Ascites was the main complication found during follow-up. This finding is clearly superior to that reported by Pariente [11], which found less than 50\% of cases. This frequency could be explained in our patients by the poor therapeutic observance, the absence of therapeutic alternative in case of refractory ascites and especially the high cost of complementary examinations during the follow-up [6].

The global mortality is variously appreciated by the authors certainly because of the mode of recruitment of the patients. Our study found $25.58 \%$ during the survival period, Bossali in Pointe Noire [5] found 68.2\% and Diarra in Mali [10] $82.5 \%$.

The low mortality rate observed in our study is probably biased by the small sample size and the short duration of follow-up.

The circumstances of death were mainly hepatic encephalopathy, gastrointestinal bleeding and hepatorenal syndrome. This is related to the advanced stage of the disease and the difficulties of management related to the insufficiency of the technical platform. 
The mortality is significantly correlated with the Child Pugh score and the oesophageal varices stage. In our study, Child Pugh stage $\mathrm{C}$ and grade III oesophageal varices were significantly correlated with high mortality $(\mathrm{p}=0.08, \mathrm{p}=0.01)$. Our results corroborate those of René Robert [15].

Bossali et al. [5] found a high mortality for Child Pugh stage C ( $\mathrm{p}=0.00034)$ and the existence of complications upon admission $(\mathrm{p}=0.0001)$. Similarly for Diarra et al. [10], the mortality is significantly high when the patients had a Child Pugh stage C score with 63.3\% ( $\mathrm{p}=0.008)$.

\section{Conclusion}

Cirrhosis remains a serious condition because the diagnosis is often made at the stage of serious complications that are life-threatening. Ascites was the main reason for consultation and hospitalization. The main causes of death identified were hepatic encephalopathy and gastrointestinal bleeding. Factors associated with mortality were Child Pugh stage C and oesophageal varices III.

\section{Conflicts of Interest}

The authors declare no conflicts of interest regarding the publication of this paper.

\section{References}

[1] Benhamou, J.P. and Erlinger, S. (2000) Maladie du foie et des voies biliaires. Flammarion, Paris, 223 p.

[2] Voitot, H. (2006) Biologie et cirrhose. Revue Francophone des Laboratoires, 387, 65-71. https://doi.org/10.1016/S1773-035X(06)80500-9

[3] Younsi, M. (2006) Histoire naturelle de la cirrhose du foie: Indicateur pronostiques et complications. Espérance Médicale, 13, 375-378.

[4] Ibara, J.-R., Ossendza, R.A., Okouo, M., et al. (1999) Les cancers primitifs du foie au Congo: Étude hospitalière de 558 cas. Médecine d’ Afrique Noire, 46, 394-397.

[5] Bossali, F., Deby, G., Atipo, B.I., et al. (2015) Evaluation de la performance des services d'hépatogastroentérologie pour la prise en charge des cirrhoses au Congo-Brazzaville en 2014. Journal Africain d' Hépato-Gastroentérologie, 9, 58-59. https://doi.org/10.1007/s12157-015-0593-9

[6] Atipo-Ibara, B.I., Ondele-Ngoli, A., Deby-Gassaye, et al. (2004) Le coût financier de la prise en charge hospitalière de la cirrhose et de ses complications au $\mathrm{CHU}$ de Brazzaville. Médecine Tropicale, 64, 50-52.

[7] Yao Bathaix, M.F., Bagny, A., Mahassadi, K.A., et al. (2015) Prognostic Factors for Cirrhosis Hospital in Abidjan (Côte d'Ivoire). Journal of Gastroenterology, 5, 103-109. https://doi.org/10.4236/ojgas.2015.57017

[8] Attia, A.K., N’Dri-Yoman, T., Sawadogo, A., et al. (2001) L'infection spontanée du liquide d'ascite chez le cirrhotique africain. Etude descriptive à propos de 12 cas. Bulletin de la Société de Pathologie Exotique, 94, 319-321.

[9] Ndububa, D.A., Ojo, O.S., Adeodu, O.O., Adetiloye, V.A., et al. (2001) Primary Hepatocellular Carcinoma in Ile-Ife, Nigeria: A Prospective Study of 154 Cases. $\mathrm{Ni}$ gerian Journal of Medicine, 10, 59-63. 
[10] Diarra, M., Konaté, A., Soukho, A., Epouse, K., et al. (2010) Aspects évolutifs de la maladie cirrhotiques dans un service d'hépatogastroentérologie au Mali. Mali Médical, 1, 42-46.

[11] Pariente, A. (2006) Décompensation ascitique. Gastroentérologie Clinique et Biologique, 30, 870-874. https://doi.org/10.1016/S0399-8320(06)73334-6

[12] Karoui, S., Hamzaoui, S., Sahli, F., et al. (2002) Mortalité au cours de la cirrhose: Prévalence, causes et facteurs prédictifs. La Tunisie Médicale, 80, 21-25.

[13] Moulion Tapouh, J.R., Njoya, O., Monabang Zoé, C., et al. (2015) Approche non endoscopique du diagnostic des varices œsophagiennes d'origine cirrhotique dans une population d'Afrique noire subsaharienne. Health Sciences and Diseases, 16, 1-5.

[14] Sehonou, J., Kodjoh, N., Sake, K.L., et al. (2010) Cirrhose hépatique à Cotonou (République du Bénin): Aspects cliniques et facteurs liés au décès. Médecine Tropicale, 70, 375-378.

[15] Robert, R. and Nanadoumgar, H. (2005) Pronostic du malade cirrhotique en réanimation. Hépato-Gastro, 12, 413-418. 